\title{
Strategi Bauran Promosi Penyelenggaraan Event (Studi Kasus Perencanaan dan Penyelenggaraan Event Pasar Murah)
}

\author{
Linda Desma Yunita ${ }^{1}$ dan Tri Handayani* ${ }^{2 *}$ \\ ${ }^{1}$ Jurusan Administrasi Niaga, Politeknik Negeri Bengkalis, Indonesia \\ ${ }^{2}$ Jurusan Administrasi Niaga, Politeknik Negeri Bengkalis, Indonesia
}

\begin{abstract}
:
The purpose of this event is to find out the promotion mix strategy used in the implementation of the Pasar Murah event either promotion to the public or to the promoter / sponsor. This project implementation method consists of several steps; project preparation, project implementation, project completion, and project reporting. At the stage of project preparation, the project concept is determined, the establishment of the committee, and the project proposal. At the stage of project implementation, the determination of the participants and sponsors, and to do the promotion strategy. At the completion stage of the project carried out the implementation of the event Pasar Murah. At the stage of project reporting carried out is the reporting of the project promotion strategy. Promotion strategy used in this project is to implement promotion mix that is, personal sales, advertising, sales promotion.
\end{abstract}

Keywords: event, promotion strategy, promotion mix

\begin{abstract}
Abstrak:
Tujuan dilaksanakan event ini adalah untuk mengetahui strategi bauran promosi yang digunakan dalam pelaksanaan event Pasar Murah baik promosi kepada masyarakat maupun kepada promotor/sponsor. Metode pelaksanaan proyek tugas akhir ini terdiri dari beberapa tahapan yaitu, persiapan proyek, pelaksanaan proyek, penyelesaian proyek, dan pelaporan proyek. Pada tahapan persiapan proyek dilakukan penentuan konsep proyek, pembentukan panitia pelaksana, dan pembuatan proposal proyek. Pada tahapan pelaksanaan proyek dilakukan penentuan peserta dan sponsor, serta melakukan strategi promosi. Pada tahapan penyelesaian proyek dilakukan pelaksanaan event Pasar Murah. Pada tahapan pelaporan proyek yang dilakukan adalah pelaporan strategi promosi proyek. Strategi promosi yang digunakan dalam pelaksanaan proyek ini adalah dengan menerapkan bauran promosi yaitu, penjualan pribadi, periklanan, promosi penjualan.
\end{abstract}

Kata Kunci: strategi promosi, bauran promosi, event

*Email korespondensi:

Tri Handayani

trihandayani@polbeng.ac.id

\section{PENDAHULUAN}

Industri MICE (Meeting, Incentive, Conference, Exhibition) dan penyelenggaran 
event serta kegiatan-kegiatan yang menarik dan bermanfaat di Indonesia mengalami kemajuan yang cukup pesat sehingga banyak diminati oleh para pelaku bisnis, dikarenakan industri ini merupakan industri yang kompleks sehingga dapat dijadikan peluang bisnis yang sangat menjanjikan bagi banyak pihak yang terlibat sebagai penyelenggara dalam kegiatan industri ini.

Agar event yang diselenggarakan berjalan sukses dan menarik publik dan promotor maka diperlukan suatu manajemen yang baik dan strategi promosi yang tepat. selain itu jenis kegiatan yang diselenggarakan juga perlu dipertimbangkan dengan baik, sehingga kegiatan tersebut tepat sasaran dan sesuai dengan kebutuhan dan keinginan publik/khalayak.

Salah satu kegiatan yang dapat diselenggarakan pada salah satu daerah di Kabupaten Bengkalis adalah penyelenggaraan pasar murah untuk masyarakat. Hal ini merupakan bentuk kontribusi yang dapat diberikan untuk membantu masyarakat dalam memenuhi kebutuhan. Adapun lokasi yang dipilih dalam penyelenggaran kegiatan ini adalah Desa Pambang Pesisir, Kecamatan Bantan, Kabupaten Bengkalis. Pemilihan lokasi tersebut didasari pada kondisi masyarakat yang sebagian besar masih tergolong ke dalam masyarakat dengan tingkat ekonomi rendah sehingga layak untuk mendapatkan bantuan dalam hal penerimaan paket sembako bersubsidi.

Tujuan artikel ini adalah untuk mengetahui strategi bauran promosi, yaitu penjualan pribadi, periklanan, promosi penjualan yang digunakan dalam pelaksanaan event Pasar Murah baik promosi kepada masyarakat maupun kepada promotor/sponsor.

\section{TINJAUAN PUSTAKA \\ Penelitian Terdahulu}

Areks, Nadjib dan Cangara (2015) meneliti tentang pengaruh penggunaan bauran promosi terhadap tingkat kunjungan wisatawan pada objek wisata alam di Kabupaten Pangkajene dan Kepulauan. Metodologi penelitian yang digunakan adalah dengan men-yebarkan kuesioner kepada 99 wisatawan yang berkunjung ke objek wisata alam di Kabupaten Pangkep. Hasil penelitian menunjukkan bahwa bauran promosi secara simultan berpengaruh nyata $(25,2 \%)$ terhadap tingkat kunjungan wisatawan pada objek wisata alam di Kabupaten Pangkep. Secara parsial hanya advertising dan word of mouth marketing yang berpengaruh nyata terhadap tingkat kunjungan wisatawan pada objek wisata alam di Kabupaten Pangkep. Unsur bauran promosi yang paling dominan berpengaruh terhadap tingkat kunjungan wisatawan pada objek wisata alam di Kabupaten Pangkep adalah word of mouth marketing.

Wajdi dan Mutmainah (2016) melakukan penelitian mengenai pengaruh promosi terhadap minat partisipasi masyarakat pada event-event tahunan di Surakarta. Metodologi penelitian yang digunakan adalah dengan menye-barkan kuesioner kepada 60 responden yang merupakan warga Surakarta. Hasil penelitian menunjukkan bahwa secara parsial bauran promosi yang meliputi periklanan, personal selling, promosi penjualan, dan publisitas berpengaruh signifikan terhadap minat partisipasi masyarakat pada event-event tahunan di Surakarta. Secara simultan periklanan, personal selling, promosi penjualan, dan publisitas juga berpengaruh signifikan terhadap minat partisipasi masya-rakat pada event-event tahunan di Surakarta. 
Penelitian yang dilakukan oleh Khanfar (2016) adalah tentang pengaruh elemen bauran promosi terhadap keputusan pembelian konsumen layanan mobile pada Perusahaan Telekomunikasi Umniah di Kota Zarqa, Jordan. Metodologi penelitian yang digunakan adalah dengan menyebarkan 440 kuesioner kepada konsumen Perusahaan Telekomunikasi Umniah di Kota Zarqa. Hasil penelitian menun-jukkan bahwa adanya pengaruh po-sitif dari advertising, personal selling, sales promotion, dan public relation terhadap keputusan pembelian konsumen. Advertising menjadi faktor yang paling penting dalam mempengaruhi keputusan pembelian konsumen.

\section{MICE}

Definisi $M I C E$ menurut Oka dalam Indrajaya (2015:2) bahwa MICE merupakan suatu rangkaian kegiatan, dimana para pengusaha atau professional berkumpul pada suatu tempat yang terkondisikan oleh suatu permasalahan, pembahasan, atau kepen-tingan yang sama. MICE terdiri dari beberapa bentuk kegiatan seperti yang dijelaskan oleh Noor (2007:4-5), yaitu pertemuan (meeting), insentif (incentive), konferensi (conference), pameran (exhibition).

\section{Meeting}

Menurut Pendit (1999:4) berarti rapat, pertemuan, atau persidangan yang diselenggarakan oleh kelompok orang yang tergabung dalam suatu asosiasi, perkumpulan atau serikat dengan adanya tujuan yang hendak dicapai dalam suatu organisasi.

2. Incentive

Istilah insentif tercantum dalam Surat Keputusan Menparpostel Nomor KM.108/HM.703/MPPt-91, Bab I Pasal I Ayat b "Perjalanan insentif merupakan suatu kegiatan perjalanan yang diselenggarakan oleh suatu perusahaan atas prestasi mereka dalam kaitan penyelenggaraan konvensi yang membahas perkembangan kegiatan perusahaan yang bersangkutan.

3. Conference

Definisi conference tercantum dalam Surat Keputusan Menteri Pariwisata Pos dan Telekomunikasi Nomor: KM.108/HM/703/MPPT-91 sebagai konferensi, kongres atau konvensi yang merupakan suatu kegiatan berupa pertemuan sekelompok orang untuk membahas masalah-masalah yang berkaitan dengan kepentingan bersama.

4. Exhibition

Menurut Surat Keputusan Menteri Pariwisata Pos dan Telekomunikasi Nomor: KM.108/HM/703/MPPT-91, Pasal 1c tentang exhibition atau pameran merupakan suatu kegiatan untuk menyebarluaskan informasi dan promosi yang ada hubungannya dengan penyelenggaraan konvensi atau yang ada kaitannya dengan pariwisata. Pengertian Exhibition menurut Oxford Dictionary adalah pertunjukan atau pameran yang dilakukan secara umum, atau kegiatan memamerkan. Pameran berdampak luas bagi peserta dan pengunjung pameran karena mereka akan menemukan banyak hal yang dapat dilihat langsung sehingga pengetahuannya terhadap suatu produk atau perusahaan akan bertambah.

\section{MANAJEMEN PEMASARAN}

Penanganan proses pertukaran memerlukan waktu dan keahlian yang banyak. Manajemen pemasaran akan terjadi apabila sekurang-kurangnya satu pihak dari pertukaran potensial memikirkan cara untuk 
mendapatkan tanggapan dari pihak lain sesuai dengan yang diinginkannya. American Marketting Association (AMA) menjelaskan dalam A.D Selang (2013:2) bahwa manajemen pemasaran sebagai seni dan ilmu memilih pasar sasaran dan mendapatkan, menjaga, dan menumbuhkan pelanggan dengan menciptakan, menyerahkan, dan mengkomunikasikan nilai pelanggan yang unggul. Sesuai dengan definisi tersebut, Kotler dan Keller dalam A.D Selang (2013:2) menyimpulkan bahwa manajemen pemasaran merupakan suatu proses yang dimulai dari proses perencanaan, pengarahan, dan pengendalian produk atau jasa, penetapan harga, distribusi, dan promosinya dengan tujuan membantu organisasi dalam mencapai tujuannya.

\section{Bauran Pemasaran}

Bauran pemasaran adalah segala sesuatu hal yang dapat perusahaan lakukan untuk mempengaruhi permintaan atas produknya, untuk mencapai tujuan pasar yang telah ditargetkan maka perusahaan harus menggunakan variabel-variabel pemasaran yang dapat dikendalikan.

Berdasarkan pendapat Kotler dan Amstrong dalam Praja (2015:2) definisi bauran pemasaran atau yang lebih dikenal dengan marketing mix adalah kumpulan alat pemasaran taktis terkendali terkendali yang dipadukan perusahaan untuk menghasilkan respons yang diinginkan dipasar sasaran. "Marketing mix adalah perangkat alat pemasaran yang digunakan perusahaan untuk mengejar tujuan perusahaannya”.

Kotler dan Keller dalam Praja (2015:2) menyimpulkan bahwa bauran pemasaran merupakan satu perangkat yang terdiri dari produk, harga, promosi dan distribusi, yang di dalamnya akan menentukan tingkat keberhasilan pemasaran dan semua itu ditujukan untuk mendapatkan respon yang diinginkan dari pasar sasaran. Bauran pemasaran terdiri dari:

1. Produk (Product)

Kotler dan Keller menjelaskan dalam Praja (2015:5) bahwa produk adalah segala sesuatu yang ditawarkan ke pasar untuk mendapatkan perhatian, dibeli, dipergunakan dan yang dapat memuaskan keinginan dan kebutuhan konsumen. Segala sesuatu yang termasuk di dalamnya adalah barang berwujud, jasa, event, tempat, organisasi, ide ataupun kombinasi dari hal-hal tersebut. Menurut Tjiptono dalam Praja (2015:5), secara konseptual produk adalah pemahaman subjektif dari produsen atas sesuatu yang bisa ditawarkan sebagai usaha untuk mencapai tujuan organisasi melalui pemenuhan kebutuhan dan keinginan konsumen, sesuai dengan kompetensi dan kapasitas organisasi serta daya beli. Strategi produk yang harus dilakukan oleh perusahaan menurut Kasmir (2006) dalam Abas Sunarya. Sudaryono, dan Asep Saefullah (2011:240-241) adalah sebagai berikut:

a. Menentukan logo motto, yang harus dipertimbangkan antara lain; harus memiliki arti (dalam arti positif), harus menarik perhatian, dan harus mudah diingat.

b. Menciptakan merek. Merek atau tanda produk supaya dikenal oleh konsumen mengenai sesuatu (barang/jasa) yang ditawarkan. Penciptaan merek harus mempertimbangkan; mudah diingat, terkesan hebat dan modern, memiliki arti (dalam arti positif), serta menarik perhatian.

c. Menciptakan kemasan. Kemasan atau bungkus produk harus memenuhi 
beberapa persyaratan; kualitas kemasan tidak mudah rusak, bentuk dan ukuran termasuk desain harus menarik, serta warna yang menarik.

d. Keputusan label. Label adalah sesuatu yang dilekatkan pada produk yang ditawarkan dan merupakan bagian dari kemasan. Di dalam label harus dicantumkan; siapa yang membuat, dimana dibuat, kapan dibuat, cara menggunakan, waktu produksi dan kadaluarsa, serta informasi lainnya.

\section{Harga (Price)}

Dijelaskan Kotler dan Keller dalam Praja (2015:6), harga adalah sesuatu yang harus dikorbankan untuk mencapai tujuan tertentu. Harga merupakan salah satu penentu keberhasilan suatu perusahaan karena harga menentukan seberapa besar keuntungan yang akan diperoleh perusahaan dari penjualan produknya baik berupa barang atau jasa. Tujuan penetapan harga sebagai berikut :

a. Mendapatkan keuntungan sebesarbesarnya dengan menetapkan harga yang kompetitif.

b. Mempertahankan perusahaan, dari marjin keuntungan yang didapat perusahaan akan digunakan untuk biaya operasional perusahaan.

c. Mengelola Return On Investment (ROI), perusahaan pasti menginginkan balik modal dari investasi yang ditanam pada perusahaan sehingga penetapan harga yang tepat akan mempercepat tercapainya modal kembali/ROI.

d. Menguasai pangsa pasar, dengan menetapkan harga rendah dibandingkan produk pesaing, dapat mengalihkan perhatian konsumen dari produk kompetitor yang ada di pasaran e. Mempertahankan status quo, ketika perusahaan memiliki pasar tersendiri, maka perlu adanya pengaturan harga yang tepat agar dapat tetap mempertahankan pangsa pasar yang ada.

Menurut Abas Sunarya. Sudaryono, dam Asep Saefullah (2011:241-242) penentuan strategi harga sangat penting untuk diperhatikan mengingat harga produk merupakan salah satu penyebab laku atau tidaknya produk yang ditawarkan. Strategi harga yang salah akan berakibat fatal terhadap produk yang ditawarkan dan berakibat tidak lakunya produk tersebut di pasar. Tujuan penentuan strategi harga secara umum menurut Kasmir (2006) adalah sebagai berikut:

a. Untuk bertahan hidup. Penetapan harga produk dibuat semurah mungkin, tujuannya supaya produk laku di pasaran. Dengan harga yang murah, tetapi masih ada margin laba, dibanding harga pesaing dekat, biasanya produk akan dapat bertahan hidup.

b. Untuk memaksimalkan laba. Keputusan strategi harga bertujuan agar penjualan meningkat, sehingga laba menjadi maksimal. Penetapan harga produk dapat tinggi atau dengan harga relatif murah.

c. Untuk memperbesar market share. Tujuan strategi penetapan harga adalah untuk memperluas atau memperbesar jumlah pelanggan. Penetapan harga yang relatif murah diharapkan dapat meningkatkan jumlah pelanggan dan pelanggan perusahaan pesaing terdekat beralih ke produk yang kita tawarkan.

d. Mutu produk. Untuk memberikan kesan bahwa produk yang ditawarkan 
memiliki kualitas yang tinggi atau lebih tinggi dari kualitas para pesaing dekat. Umumnya harga ditetapkan setinggi mungkin karena ada anggapan bahwa produk yang ditawarkan berkualitas, sehingga produk yang lebih tinggi dibandingkan dengan harga produk pesaing masih dinilai wajar.

e. Karena pesaing. Strategi keputusan harga produk dilakukan setelah melihat harga dari pesaing, bertujuan agar harga yang ditawarkan lebih kompetitif dibanding harga yang ditawarkan pesaing terdekat. Artinya, dapat melebihi atau lebih rendah dibanding harga produk yang sama dari pesaing tersebut.

\section{Tempat (Place)}

Kotler dan Keller dalam Praja (2015:6) menjelaskan bahwa penempatan disini diartikan sebagai saluran distribusi. Penempatan ini termasuk aktivitas perusahaan untuk menyalurkan produk atau jasa tersedia bagi konsumen dalam sejumlah saluran distribusi dan outlet yang memungkinkan konsumen dapat dengan mudah memperoleh suatu produk. Selain hal itu, pemilihan tempat atau lokasi memerlukan pertimbangan yang cermat terhadap beberapa faktor berikut :

a. Akses, misalnya lokasi yang mudah dijangkau sarana transportasi umum.

b. Visibilitas, misalnya lokasi yang dapat dilihat dengan jelas dari tepi jalan.

c. Lalu lintas (traffic), di mana ada dua hal yang perlu dipertimbangkan, yaitu banyaknya orang yang lalu-lalang dapat memberikan peluang besar terjadinya kepadatan dan kemacetan lalu lintas dapat pula menjadi hambatan.

d. Tempat parkir yang luas dan aman. e. Ekspansi, tersedia tempat yang cukup untuk perluasan usaha di kemudian hari.

f. Lingkungan, yaitu daerah sekitar yang mendukung jasa yang ditawarkan.

g. Persaingan, yaitu lokasi pesaing.

h. Peraturan pemerintah.

Seorang wirausaha harus mampu memilih strategi yang tepat dalam distribusi produk. Menurut Kasmir (2006) dalam Abas Sunarya. Sudaryono, dam Asep Saefullah (2011:245) strategi yang tepat dalam menetapkan saluran distribusi produk memiliki beberapa fungsi, yaitu:

a. Fungsi transaksi, yaitu:

Fungsi penyaluran produk, mencakup bagaimana pengusaha menghubungi dan mengkomunikasikan produknya ke calon pelanggan. Fungsi ini membuat mereka sadar terhadap produk yang telah ada dan menjelaskan kelebihan serta manfaat produk tersebut.

b. Fungsi logistik, yaitu:

Fungsi yang meliputi pengangkutan dan penyortiran produk, termasuk tempat menyimpan, memelihara dan melindungi produk. Fungsi ini penting agar produk yang diangkut dapat tiba tepat waktu dan tidak rusak.

c. Fungsi fasilitas, yaitu:

Mencakup fungsi penelitian dan pembiayaan. Penelitian produk yakni mengumpulkan informasi tentang jumlah penyalur atau agen dan pelanggan lainnya, sedangkan pembiayaan adalah memastikan bahwa para penyalur atau agen memiliki uang jaminan yang cukup untuk memudahkan aliran produk melalui saluran distribusi sampai ke konsumen akhir dengan selamat, tepat waktu dan tepat jumlah. 
4. Promosi (Promotion)

Buchari Alma dalam Praja (2015:7) menjelaskan bahwa definisi promosi adalah suatu bentuk komunikasi pemasaran yang merupakan aktivitas pemasaran yang berusaha menyebarkan informasi, mempengaruhi, membujuk, dan atau mengingatkan pasar sasaran atas perusahaan dan produknya agar bersedia menerima, membeli, dan loyal pada produk yang ditawarkan perusahaan yang bersangkutan. Tujuan utama dari promosi yaitu menginformasikan, mempengaruhi dan membujuk serta mengingatkan pelanggan sasaran tentang perusahaan dan bauran pemasarannya. Secara rinci ketiga tujuan promosi tersebut dapat dijabarkan sebagai berikut:

a. Menginformasikan (informing)

b. Membujuk pelanggan sasaran (persuasing)

c. Mengingatkan (reminding)

\section{Strategi Promosi}

Definisi strategi menurut Ireland, et al. dalam Radianto dan Halim (2016:2) merupakan serangkaian komitmen, tindakan terpadu dan terkoordinasi yang dirancang untuk mengeksploitasi kompetensi inti guna mendapatkan keunggulan kompetitif. Strategi menurut David (2012) adalah sarana bersama dengan tujuan jangka panjang yang hendak dicapai oleh perusahaan. Strategi promosi menurut Haryanto (2013) adalah cara yang biasa digunakan untuk meningkatkan citra perusahaan, dengan mengiklankan produk dan brand perusahaan melalui beberapa media. Dari beberapa definisi tersebut dapat disimpulkan bahwa strategi promosi merupakan kegiatan yang direncanakan dengan maksud membujuk, merangsang konsumen agar mau membeli produk perusahaan sehingga tujuan untuk meningkatkan penjualan diharapkan dapat tercapai.

\section{Bauran Promosi}

Menurut Kotler dan Amstrong dalam Radianto dan Hedynata (2016:3) mendefinisikan bauran promosi sebagai perpaduan spesifik alat-alat promosi yang digunakan perusahaan untuk mengkomunikasi-kan value ke customer secara persuasif dan membangun customer relationship. Bauran promosi terdiri dari 8 model, yaitu:

1. Iklan/ Advertising, merupakan semua bentuk terbayar dari persentasi nonpersonal dan promosi ide, barang atau jasa melalui sponsor yang jelas melalui media cetak (koran dan majalah), media penyiaran (radio dan televisi), media jaringan (telepon, kabel, satellite, wireless), dan media elektronik (rekaman suara, rekaman video, $C D-R O M$, halaman website), dan media pameran (billboard, papan petunjuk, dan poster). Menurut Tjiptono (2008) dalam Michael Lontoh (2016:3), iklan adalah bentuk komunikasi tidak langsung yang didasari pada informasi tentang keunggulan atau keuntungan suatu produk, yang disusun sedemikian rupa sehingga menimbulkan rasa menyenangkan yang akan mengubah pikiran seseorang untuk melakukan pembelian.

2. Promosi Penjualan/ Sales Promotion, merupakan berbagai insentif jangka pendek untuk mendorong percobaan atau pembelian produk atau jasa termasuk promosi konsumen (seperti sampel, kupon, dan premi), promosi perdagangan (iklan dan tunjangan), dan bisnis dan promosi tenaga penjualan (kontes untuk reputasi penjualan). 
3. Acara dan Pengalaman/ Event and Experiences, merupakan kegiatan dan program yang disponsori perusahaan yang dirancang untuk menciptakan interaksi harian atau merek khusus terkait interaksi dengan konsumen, termasuk seni olahraga, hiburan, dan menyebabkan acara atau kegiatan menjadi kurang formal.

4. Hubungan Masyarakat dan Publisitas/ Public Relations and Publicity, merupakan berbagai program yang diarahkan secara internal kepada karyawan dari perusahaan atau konsumen luar, perusahaan lain, pemerintah, dan media untuk mempromosikan, membangun hubungan antar perusahaan dengan publik, melindungi dan membangun citra perusahaan atau produk komunikasi individu yang positif. Menurut Kotler dan Armstrong (2008) dalam Michael Lontoh (2016:3), pemasaran langsung (direct marketing) adalah hubungan langsung dengan konsumen individual yang ditargetkan secara hati-hati untuk meraih respon segera dan mencapai hubungan pelanggan yang abadi.

5. Penjualan Personal/ Personal Selling, merupakan interaksi tatap muka yang dilakukan oleh tenaga penjualan perusahaan dengan satu atau lebih pembeli prospektif untuk tujuan melakukan pertemuan penjualan, presentasi pribadi, menjawab pertanyaan, pengadaan pesanan, membuat penjualan, dan hubungan pelanggan. Menurut Tjiptono (2008) dalam Michael Lontoh (2016:3), personal selling adalah komunikasi langsung (tatap muka) antara penjual dan calon pelanggan untuk memperkenalkan suatu produk kepada calon pelanggan dan membentuk pemahaman pelanggan terhadap produk sehingga mereka kemudian akan mencoba dan membelinya.

6. Pemasaran Langsung/ Direct Marketing, merupakan penggunaan surat, telepon, fax, e-mail, atau internet untuk berkomunikasi atau berhubungan secara langsung dengan meminta respon atau tanggapan dan melakukan dialog dari pelanggan dan prospek tertentu.

7. Pemasaran Interaktif/Interactive Online Marketing adalah kegiatan dan program online yang dirancang untuk melibatkan pelanggan atau prospek dan secara langsung atau tidak langsung meningkatkan kesadaran memperbaiki citra, atau menciptakan penjualan produk dan jasa.

8. Pemasaran dari mulut ke mulut/ Word of Mouth Marketing, merupakan komunikasi lisan, tertulis, dan elektronik antar masyarakat yang berhubungan dengan keunggulan atau pengalaman membeli atau menggunakan produk atau jasa.

\section{METODE DAN PROSES PENYE- LESAIAN}

\section{Rencana Persiapan}

Penentuan konsep proyek, pembentukan panitia pelaksana proyek/kegiatan, dan pembuatan proposal proyek.

\section{Rencana Pelaksanaan}

Perencanaan jadwal proyek, promosi proyek kepada calon sponsor dan calon donatur, dan promosi proyek kepada masyarakat.

\section{HASIL DAN PEMBAHASAN \\ Persiapan Pasar Murah}

Persiapan sangat diperlukan untuk mencapai keberhasilan dalam melaksanakan 
suatu kegiatan. Persiapan yang dilakukan dengan baik dan matang akan mewujudkan kelancaran dan keberhasilan optimal suatu kegiatan. Dalam pelaksanaan Event ini dilakukan beberapa persiapan, yaitu:

1. Penentuan Konsep Proyek

Langkah awal dalam mempersiapkan sebuah kegiatan adalah menentukan konsep yang akan digunakan. Dalam penentuan konsep proyek juga ditentukan beberapa hal mengenai kegiatan tersebut, seperti target dan lokasi, tema dan jadwal pelaksanaan, serta informasi yang dibutuhkan untuk mempersiapkan event yaitu mencakup informasi tentang perusahaan/ instansi sponsor, proses dan prosesur perizinan, serta sarana dan prasarana yang dibutuhkan dalam event.

2. Pembentukan panitia pelaksana proyek

Job description dan struktur kepanitiaan dibentuk dalam kepanitiaan. Pembentukan job description akan memudahkan panitia untuk mengetahui tugasnya sehingga dapat bekerja dengan baik. Koordinasi yang terjalin dengan baik dalam kepanitian dapat menghindari miss communication saat melaksanakan tugasnya masing-masing.

3. Pembuatan proposal proyek

Proposal ini digunakan untuk dalam mempromosikan kegiatan dengan tujuan untuk memperoleh bantuan dana dan dukungan. Pembuatan proposal ini dibuat oleh bagian kesekretariatan melalui koordinasi bagian promosi, bagian keuangan, dan bagian penyelenggara.

\section{Pelaksanaan Pasar Murah}

Beberapa aktivitas yang dilakukan pada tahap ini adalah menentukan peserta dan sponsor, dan melakukan promosi.

Peserta ditentukan dengan memperoleh informasi kepada pemerintah terkait, yaitu kantor Desa Pambang Pesisir. Kemudian menjalin kerja sama dengan perangkat desa untuk mensosialisasikan program kegiatan untuk disampaikan kepada masyarakat setempat.

\section{Promosi}

Promosi merupakan suatu aktifitas untuk menyebarluaskan informasi mengenai kegiatan kepada pihak yang terlibat dan sasaran yang telah ditetapkan sebelumnya sehingga dapat menarik minat masyarakat untuk berpartisipasi pada kegiatan tersebut. Berikut merupakan bentuk promosi yang dilakukan:

Pelaksanaan Pasar Murah menggunakan strategi promosi yaitu dengan menerapkan bauran promosi yang berupa Penjualan Pribadi (Personal Selling), Periklanan (Advertising) dan Promosi Penjualan (Sales Promotion) untuk memberikan informasi mengenai kegiatan kepada masyarakat agar dapat berpartisipasi pada kegiatan tersebut.

\section{Penjualan Pribadi (Personal Selling)}

Jenis penjualan pribadi yang dilakukan pada kegiatan Pasar Murah yaitu melakukan promosi kepada calon sponsor dan donatur.

Pada kegiatan Pasar Murah pihak panitia penyelenggara menjalin kerjasama sponsorship dengan Bank CIMB Niaga Cabang Dumai yang menjadi sponsor pendamping.

Penjualan pribadi pada kegiatan ini juga dilakukan dengan mengadakan sosialisasi antara panitia inti kepada pihak yang terlibat seperti PJ Kepala Desa, Ketua Forum RT, Kepala Dusun serta aparatur Desa Pambang Pesisir. Sosialisasi diadakan untuk menjelaskan kegiatan pasar murah seperti konsep kegiatan, rencana 
pelaksanaan dan penyebaran kupon beserta brosur yang diwakili oleh Ketua Forum RT.

\section{Periklanan (Advertising)}

Jenis periklanan yang dilakukan adalah dengan mendesain label pada kemasan, menyebarkan brosur kepada masyarakat secara langsung dan memasang baliho dan spanduk pada saat kegiatan berlangsung.

\section{Promosi Penjualan (Sales Promotion)}

Promosi penjualan yang dilakukan adalah dengan menyebarkan kupon yang memberikan informasi bahwa masyarakat akan mendapat kesempatan untuk memperoleh sesu-atu yang istimewa. Masyarakat yang memiliki kupon tersebut akan men-dapatkan harga sembako yang telah disubsidi.

\section{KESIMPULAN}

Berdasarkan pelaksanaan kegiatan/ event pasar maka dapat diambil kesimpulan sebagai berikut:

1. Kegiatan ini telah melalui 4 (empat) tahap, yaitu persiapan proyek, pelaksanaan proyek, penyelesaian proyek, dan pelaporan proyek. Beberapa hal yang dilakukan pada tahap persiapan proyek adalah penentuan konsep proyek, pembentukan panitia pelaksana proyek, dan pembuatan proposal proyek. Pada tahap pelaksanaan proyek dilakukan penentuan peserta dan sponsor, serta melakukan promosi. Selanjutnya pada tahap penyelesaian proyek dilakukan pelaksanaan kegiatan Pasar Murah pembuatan laporan strategi promosi.

2. Strategi promosi yang dilakukan dalam pelaksanaan kegiatan Pasar
Murah adalah dengan menerapkan bauran promosi, yaitu penjualan pribadi (personal selling), periklanan (advertising), dan promosi penjualan (sales promotion). Penjualan pribadi dilakukan dengan mengadakan sosialisasi kegiatan ke-pada aparatur desa, perangkat desa Desa Pambang Pesisir, serta melakukan promosi kepada calon sponsor dan donatur. Periklanan dilakukan dengan menyebarkan brosur dan kupon, serta memasang baliho dan spanduk pada saat kegiatan berlangsung. Promosi penjualan dilakukan dengan membagikan kupon kepada peserta penerima paket sembako.

\section{DAFTAR PUSTAKA}

A. Khanfar, Iyad. (2016). The Effect of Promotion Mix Elements on Consumers Buying Decision of Mobile Services: The case of Umniah Telecommunication Company at Zarqa City Jordan. European Journal of Business and Management, Vol. 8, No. 5

A.D Selang, Christian. (2013). Bauran Pemasaran (Marketing Mix) Pengaruhnya Terhadap Loyalitas Konsumen Pada Fresh Mart Bahu Mall Manado. Jurnal EMBA, Vol.1, No. 3, Hal. 71-80

Areks, Erna, Muh. Nadjib, Syaifullah Cangara. (2015). Pengaruh Penggunaan Bauran Promosi Terhadap Tingkat Kunjungan Wisatawan Pada Objek Wisata Alam di Kabupaten Pangkajene dan Kepulauan. Jurnal Komunikasi KAREBA, Vol. 4 No. 4

E. D Radianto, Dr. Wirawan dan Halim, Natalia. (2016). Perancangan 
Strategi Promosi Bagi Perusahaan Dessert Factory. Jurnal Manajemen dan Start-Up Bisnis, Vol. 1, No.2

Hedynata, Livia Marceline dan E.D Radianto, Wirawan. (2016). Strategi Promosi Dalam Meningkatkan Penjualan Chocolate Potato Snack. Jurnal Manajemen dan Start-Up Bisnis, Vol. 1, No.1

Indrajaya, Titus. (2015). Potensi Industri MICE (Meeting, Incentive, Conference And Exibition) di Kota Tangerang Selatan, Provinsi Banten. Jurnal Ilmiah WIDYA, Vol. 3, No. 2 Lontoh, Michael N. (2016). Analisis Pengaruh Bauran Promosi Terhadap Keputusan Pembelian Mobil Toyota Pada PT. Hasjrat Abadi Manado Cabang Medan. Jurnal Berkala Ilmiah Efisiensi, Vol. 16, No. 01
Noor, Any. (2007). Globalisasi Industri MICE. Alfabeta. Bandung

Praja, Bryan Sacaksana Setya. 2015. Pengaruh Bauran Pemasaran (Marketing Mix) Terhadap Loyalitas Konsumen Produk Fanta PT. CocaCola Amatil Indonesia di Kota Semarang

Situmorang, Alam. (2007). Ekonomi untuk SMA dan MA Kelas X. KTSP Standar Isi 2006. Esis

Sunarya, Abas PO, Sudaryono dan Asep Saefullah. (2011). Kewirausahaan. Edisi I. Andi. Yogyakarta.

Wajdi, M. Farid, Siti Mutmainah. (2016). Promosi Event Tahunan dan Minat Partisipasi Masyarakat Kota Surakarta. Jurnal FEB UMSIDA 